\title{
Challenges of enhancement of the procedural guarantees of the rights and interests of participants in criminal proceedings
}

\author{
Dildora Bazarova, Tashkent state university of law The Republic of Uzbekistan
}

\begin{abstract}
Nowadays, one of the foremost squeezing issues in Uzbekistan is as takes after and within the share of states on the way of democratization of open life, where the most esteem is the human being, the arrangement of solid and effective guarantees of rights and flexibilities of the individuals, its security, particularly within the circle of criminal procedures, running within the climate of pressure and negative enthusiastic and mental stack for the share of participants of criminal procedures. It can not be contended that the issues of guaranteeing and actualizing human rights ensures, counting the method of its support in criminal procedures, have been insulant inquired in profundity and comprehensively.
\end{abstract}

Keywords: criminal proceedings, criminal procedural guarantees, evidence, legislations, rights of participants

Received: 14.12.2020 $\quad$ Accepted: 12.01.2021 $\quad$ Published: 07.02.2021

\section{INTRODUCTION}

Currently, there is a need to improve the theoretical provisions of the principle protection of human rights and freedoms in criminal proceedings, as well as in the development of an operating mechanism and implementation of this principle. Renewing Uzbekistan is not only recognizes the main human rights and freedoms, but also raises their protection into one of the main tasks of criminal proceedings and its most important function, the implementation of which is carried out by the preliminary investigation bodies, and other law enforcement agencies interacting with them bodies [1].

Since one of the parties to the procedural legal relationship is always a state body or an official vested with powers of authority that acquire special significance in the criminal process procedural guarantees of the person, protection of his legal rights and interests, ensuring the right to judicial protection.

Real ensuring the rights of the individual, firstly the accused is a criterion for assessing democracy, humanism of the criminal process. The basis of guarantees of individual rights in the field of criminal process are fixed and secured by Constitution of human and civil rights and freedoms. These fundamental norms are specified in the criminal procedure law in relation to the stages of process and the rights are granted to participants and other subjects of criminal proceedings.

A suspect, an accused (defendant, convicted person) can defend their rights both personally and with the help of a defender, representatives. The law guarantees the rights of the victim, civil plaintiff, civil defendant and other participants in the process (witnesses, experts, specialists, attesting witnesses, translators and etc.) [3].

The system of guarantees covers the whole range of funds ensuring human rights in the course of criminal proceedings. The guarantee of the right is the observance by another person's obligations ensuring the conditions for the implementation of his right. Guarantees of human rights and legitimate interests

in criminal proceedings serve as a means of ensuring the possibility of the actual usage of the provided his right. In the mechanism of ensuring human rights, it is necessary to substantively distinguish between rights and guarantees of their proper provision, including their implementation by participants in criminal proceedings (for example, the service of a text with procedural rights of a suspect

during the arrest of a suspected person) and defense in cases offenses.

In criminal proceedings, all subjects are endowed with procedural rights, the foundations of which are provided by the Constitution of Uzbekistan, Criminal procedure law. Guarantees of human rights and freedoms are considered as a set of special legal means and methods by which rights and freedoms are realized and protected, their violations are suppressed, violated rights are restored. The guarantees of the realization of human rights and freedoms include the enshrined

legal norms, the limits of their implementation, methods concretization; legal facts related to their provision; procedural forms of exercise of rights and freedoms; incentives for their legitimate implementation [2].

Among the criminal procedural guarantees, a special place belongs to the constitutional provisions acting in the criminal process as its principles, basic principles of criminal proceedings. They are the basic 
in the mechanism for ensuring human rights. References to inalienable human rights are contained in the constitutional texts of Italy, Spain, France, Germany and other countries. However, even recognizing the over-positive nature of some human rights, it should be noted that the positive consolidation of fundamental rights by the Constitution is a necessary prerequisite for their protection by the state [6].

Within the framework of the criminal procedure, all procedural guarantees in the aggregate ensure the achievement of the tasks, Procedural guarantees are united by a common purpose, the mechanisms of their actions are also interconnected. The mechanism of action of legal guarantees rights that who participating in criminal proceedings is a system of procedural norms and participants in the criminal proceedings. The purpose of the system of guarantees of rights and the legitimate interests of a person are expressed in the fact that in criminal proceedings firstly, they act as a means to minimize judicial errors in relation to these participants in criminal proceedings, thereby implementing the requirements. Secondly, it is a means of enabling actual use of the rights are granted to them and give them real character. The effectiveness of all systems of ensuring rights is determined by the following criteria: the presence of each procedural right of an appropriate procedural guarantee; conformity between general and special guarantees; the presence rights which may be limited to more than one. General warranties include those with universal content and the ability to provide necessary protection of the different nature of the rights of the suspect and the accused; general conditions and special means providing economic, social, political and spiritual foundations of the existence of society. Special guarantees are procedural security means that are designed to protect individual rights of the suspect, the accused, legal means of direct enforcement of and protection of rights [5].

An important role in ensuring the legality and validity of criminal proceedings is played by procedural guarantees, i.e. those are established by procedural law means that create conditions for the fulfillment tasks of criminal proceedings, fair justice. Procedural guarantees are actually subjective rights; these are procedural means that protect, ensure the rights and legitimate interests of participants of criminal procedure: "Established by norms of the criminal procedural law, different in their specific content means, in the aggregate, providing people, participating in the case with the opportunity to exercise the rights". E.F. Kutsova understands the guarantees of individual rights in the criminal proceedings, specific rights and obligations of participants in the criminal procedural relations. According to A.L. Tsypkin, procedural guarantees should include legal new norms. Other authors consider guarantees as the means are established by the norms of the criminal procedure law, different in their content, in their aggregate, are designed to provide the participants in the process with the opportunity to exercise, the rights are granted to them. To the above, it is possible to add that legal guarantees should be understood as certain ways of exercising rights and freedoms by the participants of certain legal relations [4].

Procedural and legal guarantees are contained legal means in the norms of law that provide all subjects of criminal procedural activity, the ability to fulfill obligations and use the granted rights. The opinion that procedural guarantees have

complex content, this is the "procedural form (grounds, procedure, conditions) for their implementation and implementation", and an independent means of ensuring the rights and legitimate interests of the subjects of criminal proceedings (citizens and legal entities and persons), and "the possibility of an offensive for violators of the criminal procedure law (officials), certain types of responsibility and the application of sanctions to the relevant branch of law".

It is necessary to distinguish between procedural guarantees of justice and guarantees of individual rights and freedoms. Procedural human rights are guaranteed by those procedural norms that enshrine the subjective rights of participants in the criminal proceedings, corresponding them with procedural rights - duties of officials - people, bodies that conducting legal proceedings, their procedural activities and the procedural activities of a defense attorney in the course of which they receive their implementation. In the system of procedural guarantees, guarantees of the subjective rights of the individual and guarantees public interest are aimed at ensuring law and order. These guarantees work closely together, however their identification is not permissible, because it leads to erosion purposes of criminal proceedings. Personal procedural guarantees, for example, the suspect and the accused, the stipulated special rules formulated by law. separate independent provisions, elements of principles or order (form), or in the form of the rights and obligations of the suspect and the accused, their representatives, defender, rights and duties of officials and bodies by their essences that are aimed, ensured the implementation and protection of rights, their legitimate interests and obligations [6].

\section{METHODOLOGY}

The human rights provisions of international instruments are important, especially in consideration of that the criminal proceeding is one of the most important areas of State activity and the only sphere where the state coercive measures are most widely and intensively applied. As evidenced by law 
enforcement practice of criminal proceedings the current system of guarantees of ensuring the rights and freedoms prescribed by the Criminal Procedure Code is not sufficiently perfect and does not fully ensure that the concerned persons are effectively protected from the crimes committed or are protected from criminal prosecution, as that is required by international standards of criminal justice administration. Initially, it seems important to establish in detail in the national criminal procedure legislation the key international norms for the protection of individual rights and freedoms, as well as to resolve the organizational and legal issues, that is, criminal procedure forms consistent with the provisions of international instruments in the proceedings in specific criminal cases.

Each participant in the criminal process has its own function, that is, its own

performs a service function that represents the direction of activity. This nature of functions is determined by the tasks that performed by these participants in the process and their protected interests. Criminal proceedings are under applicable criminal procedure law.

The participants in the proceedings are classified as follows:

1. State bodies are responsible for criminal proceedings and officials:

a) the Court (Article 28); b) the prosecutor (Article 33); c) investigator (Article 35); d) the head of the investigation department, division, subdivision, group and deputy (Article 37); e) inquiry bodies (Article 38); The moral and personal interests, materials in criminal proceedings, the defending participants are: a) the accused (Article 45); b) suspicion (Article 46); c) the victim (Article 54);

2. As participants in the criminal proceedings, criminal proceedings in the manner is prescribed by law, enforceable and statutory law and government agencies, officials and citizens are told:

a) the accused (Article 45); b) suspicion (Article 46); c) the victim (Article 54);

(Article 56); d) a civil plaintiff (Article 57); e) civil liability (Article 58);

1. Participants represent the interests: a) a lawyer (Article 49); b) the lawyer of the witness (Article 66); c) a legal representative (Article 60); d) representatives (Article 62).

2. Participants represent the interests of others: a) a lawyer (Article 49); b)a witness's lawyer (Article 66); c) a legal representative (Article 60);

d) representatives (Article 62).

3. Participants are on behalf of the public: a) public associations, communities and their representatives (Articles 40-41); b) public prosecutors (Article 43);

c) public defenders (Article 44).

4. Helping to increase the efficiency of participants in criminal proceedings

a) witness (Article 65); b) an expert (Article 67); c) translator (Article 71); 73); e) a specialist (Article 69); f) court clerk (Article 32).

d) impartially (Article

\section{FINDINGS AND DISCUSSION}

The participants in the criminal proceedings have their own powers accurate and criminal proceedings within the scope of serve the fulfillment. The participants in the criminal proceedings are classified into groups according to placing before functions, to be maintained or performed.

CLASSIFICATION is divided into four groups:

1) Public associations, communities and their members involved in the criminal proceedings: a) Congregation accuser b) Congregation

2) Government agencies that are responsible for criminal proceedings:

- Judge

- People's Advisers

- Secretary of the Court

- Prosecutor

- Investigator

- Investigation Department Division, Division, Team Leader and Deputy Head

- Inquiry authorities

- Head of Inquiry Agency and Inquirer

3) Defending individuals' interests in criminal proceedings

$\checkmark$ Defendant

$\checkmark$ The suspect

$\checkmark$ Defendant

$\checkmark \quad$ The victim

$\checkmark \quad$ Civil plaintiff

$\checkmark$ Civil

4) Participating in criminal proceedings

$\checkmark$ Witness 
$\checkmark$ Expert

$\checkmark$ Specialist

$\checkmark$ Translator

$\checkmark$ Neutral

The judiciary is the central body of government agencies and officials that are responsible for criminal proceedings. After all, it is the court that performs the function of justice and makes the final decision on the crime. Today, in the process of judicial reform, a somewhat is improved procedural order, a more efficient system of selection and appointment of judicial staff has been established, and the equality of participants in court proceedings has been strengthened by law.

It should be pointed out that the term "criminal procedure guarantees" are only used in science of criminal proceedings, but it is not applied in the national criminal procedure legislation and international legal acts about the civil rights and liberties. However, it must be borne in mind that implementation of all 'criminal procedure guarantees', that is in point of fact the scientific and theoretical term probably in many respects depends on correct legislative framework, that is along with the local, national, traditional circumstances, surely should focus on the international standards of preservation of rights and freedoms of persons upon organization and implementation of criminal proceedings.

Whereas, the list of international regulatory acts regulating the persons and civil rights and liberties protection, recognized as commonly accepted standards is quite extensive. The most significant are as follows: the Universal Declaration of Human Rights (1948); the International Covenant on Civil and Political Rights and Optional Protocol to the International Covenant (1966); Declaration on Protection of All Persons against Torture and other Cruel, Inhuman or Degrading Treatment or Punishment (1975); Declaration of Basic Principles of Justice for Victims of Crime or Abuse of Power (1985); Standard Minimum Rules for the Treatment of Prisoners (1957); United Nations Standard Minimum Rules for the Administration of Juvenile Justice ("Beijing Rules"), approved by the General Assembly of United Nations (1985); Convention against Torture and Other Cruel, Inhuman or Degrading Treatment or Punishment (1984); European Convention for the Protection of Human Rights and Fundamental Freedoms (1950); European Convention on Mutual Legal Assistance in Criminal Matters (1959); Body of Principles for the Protection of All Persons under Any Form of Detention or Imprisonment (1988), etc [7].

The provisions of the Resolution of the President of the Republic of Uzbekistan No. PR-3723 dated May 14, 2018 "On actions of radically improvement of system of criminal procedure and criminal procedure legislation" are of particular importance for the improvement of the criminal procedure in criminal cases, as one of the components (elements) of the system of guarantees of the rights of parties to the criminal proceedings, where the following are indicated among the systemic problems and shortcomings of the organizational and legal regulation of criminal proceedings:

- Legal problems in the system of criminal procedure legislation that impede the protection of rights, liberty and legitimate interests of citizens, ensuring the legitimacy of law in pretrial and trial proceedings on criminal cases;

- Unsatisfactory quality of investigation and use of data as evidence obtained with violation of procedural legislation;

- The low level of introduction into advanced information and communication technologies into legal and investigative practice.

The Concept for the Improvement of Criminal or Criminal Procedure Legislation of the Republic of Uzbekistan approved by the above-mentioned Resolution along with the others is determined the need for introducing the new forms and procedures of criminal procedure, which include:

development of simplified procedures for pre-trial and judicial proceedings, introduction of innovative forms and methods of judicial investigation;

creation of optimum mechanisms of implementation of separate legal and investigative proceedings during pretrial investigation for establishment of existence or lack of elements of crime; reforming the stage of the appointment of criminal case to trial by introducing the institution of preliminary hearing based on the principle of adversarial parties; creation of the mechanisms providing change of accusation in court proceedings including the change to grave accusation, as well as the procedural mechanism of prosecutor's waiver of prosecution; introduction of effective criminal procedure and organizational measures of protection of the witnesses, victims and persons affected by crimes; institution of depositing the testimony of witnesses and victims, mainly in cases where they cannot be questioned later for objective reasons; ensuring the effective use of information and communication technologies in judicial and investigative activity, including introduction of the Electronic Criminal Case system and "remote interrogation"; 
- further development of the institution of verification of the legality, validity and fairness of court decree, considering the new criminal procedure institutions being introduced;

creation of effective mechanisms of permission of the questions concerning execution of sentences, definitions and resolutions of court [8].

The decision-making nature of the main directions and tasks set out in the mentioned Resolution certainly requires the adoption of appropriate effective measures to implement its provisions by the Interdepartmental Commission, as well as obliges domestic criminal procedure science to significantly intensify research activities in order to study the modern legislation of foreign countries, the best practices of their law enforcement and judicial bodies, as well as the theoretical justification of the possibility and expediency of using effective and tested procedural forms and procedures in domestic criminal procedure legislation, which will strengthen guarantees of ensuring all rights of citizens determined by their procedural situation at all stages of the proceedings [9].

It is remarkable that specific steps are taken in Uzbekistan to improve the criminal procedure, its legislative and legal base aimed at optimization of the activities of the law enforcement and judicial systems and, at the same time, improving the effectiveness of the system of guarantees for the protection of the rights and freedom of parties to the criminal process, attract the attention of international organizations and their specialized units, in particular the United Nations Office on Drugs and Crime (UNODC), which in June 2018 prepared an analytical document entitled "Proposals on the concept of improving the system of criminal and criminal procedure legislation of the Republic of Uzbekistan" (further - Proposals), containing a number of very interesting recommendations, which, in the opinion of the authors, can provide effective assistance in solving the general issues of reforming criminal procedure law and its individual institutions [10].

Procedural guarantees for the protection of rights include the following:

- equality of the accused and the defense lawyer with other participants in the criminal proceedings upon presentation of evidence, statements of motions;

- personal participation in the proceedings both in the court and during the review;

- a verdict by a higher court;

- the right of the accused to appear in the pleadings after the prosecutor;

- the rule on the inadmissibility of a turn to deterioration in the review of the sentence by the courts;

- freedom to appeal against actions and decisions of state bodies and officials, participating in criminal proceedings;

- the possibility of canceling the sentence on grounds of violation of the accused people's right to defense [11].

Procedural guarantees include the principles of criminal justice, such as adversarial, presumption of innocence, administration of justice only by court, freedom of assessment, evidence, etc. For example, the presumption of innocence is an objective position, it does not depend on opinion, certain people, law enforcement officers who are detained and convinced, the presence of the guilt of the accused person. This provision is valid throughout the entire duration of the investigation, starting from the initiation of a criminal case against a specific person and until the entry of the sentence.

The significance of the presumption of innocence is mainly that the rights of person lead to criminal responsibility and at the same time provides an objective

investigation of the circumstances of the case. Violations of the presumption of innocence, deviations are inevitable, give the investigation of the circumstances of the case, character, which does not contribute to discover the truth in the case.

Of course, in order to ensure the rights of the accused person in the criminal proceedings, it is necessary for legislative consolidation of these rights, legislative regulation of the conditions for their provision, precise compliance by officials with the requirements of the law to ensure guarantees of the rights of the accused people, as well as knowledge of their rights and obligations by the participants in the criminal process and, of course, their implementation.

Particular interest for theoretical reflection has the recommendations set out in the Proposals, which relate in whole or in part to the reform of the criminal procedure form of domestic proceedings, which is closely interlinked with the content, that is, with the establishment of evidence base and impacting on the effectiveness of the observation of criminal process parties, especially during the pretrial investigation stages.

The Proposals propose to abandon the stages of pre-investigation verification and initiation of criminal proceedings, as well as integrate the provisions of the legislation from operational-search activities in the framework of a single criminal procedure. In their opinion, the rejection of such ineffective forms of organizing a pre-trial investigation should be compensated by effectively and independent judicial 
control. In addition, the authors consider it necessary to simplify the pretrial proceedings themselves, which, in their opinion, remains cumbersome, ineffective, characterized by red tape and poor provision of human rights guarantees. The several authors argue their opinions as follows:

At the beginning of the pretrial investigation, on the one hand, the rights of the victim are often violated as a result of the refusal to accept his statement about the commission of crime, and, on the other hand, the rights of the suspect, accused, detained are poorly protected. As the reasons for these violations, there are frequent cases of concealment by law enforcement officials of the facts of the submission of statements by the victims or the time and place of detention of the suspect, since this circumstance is most often associated with the desire of law enforcement agency or official to avoid a decrease in the efficiency of their work. In this regard, the authors recommend the creation of Unified Register of Criminal Investigations, for which the General Prosecutor Office of the Republic of Uzbekistan (holder) shall be responsible, and when implementing this recommendation, include The Code of Criminal Procedure of the Republic of Uzbekistan contains the relevant norms governing organizational matters, the rights and obligations of users and other conditions for the operation of the Unified Register of Criminal Investigations. At the same time, the holder should have the right to establish the parameters for entering a particular category of information into the Unified Register of Criminal Investigations, general standards for recording and identifying the use of the database, and shall be responsible for the formation of the latter.

The Unified Register of Criminal Investigations, which includes integrated databases, may contain data on suspects; different categories of crime; the progress of the investigation and the officials conducting the investigation. The Unified Register of Criminal Investigations can be considered as an initial stage in the development of the digital criminal case matrix and therefore it is necessary to study the international experience that exists in Latvia, Estonia, Kazakhstan, and Ukraine and thereby lay the foundations for the development of digitalization of the entire criminal justice chain.

The use of the Unified Register of Criminal Investigations, according to the authors, will prevent law enforcement officials from conducting investigative actions (except for urgent ones prescribed by the Code of Criminal Procedure of the Republic of Uzbekistan) at pre-trial stages before recording information about the criminal offense in the Unified Register of Criminal Investigations, as well as it shall give the victim the right to appeal against the refusal to enter his application in the Unified Register of Criminal Investigations in court.

The registration of crimes in the Unified Register of Criminal Investigations will help guarantee the rights of victims to investigate crimes committed against them and minimize cases of unjustified refusal to start criminal proceedings, as well as contribute to greater guarantee of the rights of suspects. In addition, such automation systems will simplify and significantly accelerate the work of pre-trial investigation bodies.

It should be noted that in accordance with the above stated Resolution of the President of the Republic of Uzbekistan No. PR-3723 dated May 14, 2018 "On actions of radically improvement of system of criminal procedure and criminal procedure legislation", the actions have already been taken since December 2018 for the pilot project "Electronic criminal case" in two administrative districts of Tashkent, the results of testing of which are currently being analyzed and summarized and will be used for preparation of proposals on improving the criminal and criminal procedure legislation on the introduction of electronic criminal proceedings.

Secondly, the Proposals contain a number of recommendations for expansion and strengthening the judicial control over restrictions on citizens' rights in the pre-trial stages of criminal proceedings, including:

1. Determining the court as the unique body that must pre-authorize detention in all cases except for detention at the crime scene and other exceptional cases, to verify the legality and validity of detention, and if it is committed without prior judicial authorization, to apply preventive measures to detainees, as well as to authorize any other restrictions on human rights in criminal proceedings.

2. In view of the expected expansion of judicial control at the pre-trial stages, as well as the need to separate the substantive resolution of cases from the issues resolved by the court at the pre-trial stages, it is proposed to create a separate judicial subsystem - human rights courts in the course of pretrial proceedings, which can be organized in the territory according to principles other than courts hearing criminal cases at first instance.

3. It is proposed to unify in the course of pre-trial investigation the operational and search activity (OSA) and investigative actions requiring the permission (sanction) of the court by combining tacit measures into a single system of tacit investigative actions based on the Code of Criminal Procedure of the Republic of Uzbekistan. Herewith the reformation should include in: 
- $\quad$ Extension of judicial control to the majority of unspoken investigative actions, including those covered by the concept of OSA;

Legislative details of tacit investigative actions;

Limiting tacit investigative actions in cases of serious and especially serious crimes;

Introduction of the procedure of notification of persons about conduction of secret investigative actions;

Recognition of tacit investigative protocols of similar evidentiary significance as the investigative protocols.

- $\quad$ Increasing responsibility for the illegal use of means and methods of tacit investigative actions (operational-search activities), as well as in general for illegal invasion of privacy.

The idea of unifying the investigative actions and operational-search actions in criminal procedure legislation is not new, especially since certain operational-technical measures have already been enshrined in the norms of the national Code of Criminal Procedure and are successfully used in the process of conducting investigative actions in the interests of investigating criminal cases as legitimate sources of information about the crime to form the evidence base.

\section{CONCLUSION}

The rights for human protection can be characterized as follows:

Firstly, in terms of its content, it is general law that consisting of a set of procedural rights are granted by law to a party, criminal proceedings;

Secondly, the subject matter (purpose), the law question are directed not only

to refute suspicions, accusations, but also to protect other legitimate interests, including defense from illegal and unjustified application of measures of procedural compulsion;

Thirdly, according to the methods of implementation, this right is exercised both by the suspect, the accused person, their defenders and legal representatives;

Fourthly, to ensure it (guarantees), it presupposes the obligation of the bodies carrying out criminal prosecution to realize the possibility of protection;

In conclusion, pre-trial and court proceedings are one of the most important guarantees of rights, personality in the criminal process: such a division allows to fully and comprehensively investigate and consider the case on the merits, to reveal the mistakes, to observe the rights of the individual, as well as the interests of justice. Undoubtedly, the court occupies a special position in the system of bodies guaranteeing compliance with the rule of law. Therefore, the normal activity of the court is ensured by procedural conditions. These include: independence of judges and subordination only to the law, invariability of the composition of the court, collegiality, consideration of a criminal case, spontaneity and orality, publicity, equality of citizens before the law and the court.

\section{REFERENCES}

1. The Constitution of the Republic of Uzbekistan. - Tashkent: NMIU of Uzbekistan, 2015. - 76 p.

2. Codes of the Republic of Uzbekistan. (As amended and supplemented until February 1, 2016): collection/ Ministry of Justice of the Republic of Uzbekistan: T .: "Adolat", 2016. - 1056 p.

3. The Law of the Republic of Uzbekistan "On Advocacy". New laws of Uzbekistan: (Laws and resolutions adopted at the seventh session of the Oliy Majlis of the Republic of Uzbekistan of the first convocation on December 27, 1996). K.15. - Tashkent: Adolat, 1997. - 272 p.

4. Astanov I.R. Conducting forensic investigative action as a form of using specialized knowledge in criminal cases: theory and practice. Monograph. // Responsible editor: B.B. Hidoyatov. - T .: TSUL, 2012. 236 p.

5. Criminal Procedure (General Part): A textbook for students of law institutes and faculties (under the general editorship of Z.F. Inogomjanova). - T .: TSUL, Publishing House, 2008. - 509 p.

6. Criminal Procedure (Special Part): A textbook for students of law faculties of law universities and colleges / Edited by Z.G. Inogomjanova. - T: TSUL, 2008. - 359 p.

7. Inomjonov Sh.X. Problems of presenting and using evidence in criminal proceedings. Scientificmethodical manual. . -T .: "Adolat", 2003.

8. Inogomjonova Z.F., Tolaganova G.Z. Problems of criminal procedureTashkent: TSUL, 2006. - 155 p.

9. Inogomjonova Z.F. Judicial control in criminal proceedings. Study guide. - T: TSJI Publishing House. 2007. 191p.

10. Inogomjonova Z.F. Judicial review during the preliminary investigation and the appointment of a criminal case for trial. (Monograph) .- T .: TSUL, 2006. -156 p. 
11. Tolaganova G.Z., Sh.F.Fayziyev, D.B.Bazarova. Criminal procedural law. Textbook. - T .: TSUL, Publishing House, 2014.- 938 p.

12. Kalinovskiy K.B., Fayziyev Sh.F. Criminal proceedings in foreign countries. -T.: TSUL, Publishing House, 2010. - 486 p.

13. Forensic tactics: Textbook. - Tashkent: Academy of the Ministry of Internal Affairs of the Republic of Uzbekistan, 1996. - 215 p.

14. Fayziyev Shokhrud Farmonovich Medical law and features of legal relations arising in the provision of medical services. International journal of pharmaceutical research Volume 11, Issue 3, July - Sept, $2019 \quad$ P. $1197-1200 \quad$ doi:10.31838/ijpr/2019.11.03.088 http://www.ijpronline.com/ViewArticleDetail.aspx?ID=11016

15. Bryanskaya Elena, Fayziev Shokhrud, Altunina Anna, Matiukha Alena Topical Issues of an Expert Report in the Process of Proving in a Criminal Examination. International Journal of Engineering and Advanced Technology (IJEAT) ISSN: 2249 - 8958, Volume-9 Issue-1, October 2019 5345-5349 DOI: $\quad 10.35940 /$ ijeat.A2946.109119 https://www.ijeat.org/wpcontent/uploads/papers/v9i1/A2946109119.pdf

16. Fayziev Shokhrud (2019) Legal Aspects of Transplantology in the Republic of Uzbekistan. Systematic Reviews in Pharmacy, ISSN: 0976-2779, Vol: 10, Issue: 2, Page: 44-47 doi: $10.5530 /$ srp.2019.2.08 http://www.sysrevpharm.org//fulltext/1961575419211.pdf?1586863081

17. Tulaganova, G. Some issues of observance of international legal norms of fight against legalization of criminal incomes in the Republic of Uzbekistan Journal of Advanced Research in Dynamical and Control Systems 12(2 Special Issue), c. 143-155

18. Bazarova D. Some problems of counteracting crimes related to laundering of illegal proceeds in Uzbekistan Journal of Advanced Research in Dynamical and Control Systems. Volume 11, Issue 7, 2019, Pages 873-885 